\title{
Effect of As-Cast Structure and Macrosegregation on Mechanical Properties in Direct-Quenched Low- Alloy Ultrahigh-Strength Steel
}

\author{
S. KOSKENNISKA, A. KAIJALAINEN, T. PIKKARAINEN, S. MEHTONEN, \\ D. PORTER, and J. KÖMI
}

\begin{abstract}
The effect of as-cast structure and macrosegregation on the mechanical properties of a direct-quenched low-alloy martensitic ultrahigh-strength aluminum killed and calcium treated steel cast at different superheats was studied. Samples from the castings were laboratory hot rolled with two different finishing rolling temperatures to distinguish the effect of hot rolling. Using optical emission spectrometry, the steel composition was analyzed as a function of slab thickness in order to detect the variations in steel chemistry due to macrosegregation. Further, hardness profiles, prior austenite grain sizes and tensile and impact toughness were determined for the hot-rolled specimens. It was found that interdendritic segregation was more intense at the higher superheat, which led to more pronounced positive segregation in the columnar-to-equiaxed transition (CET) zone, and negative segregation between CET and the centerline. These macrosegregation patterns were inherited by the hot-rolled samples causing local variations in hardness, which followed the variations in carbon content. However, altering the superheat had a minor effect on the nominal transformed microstructures and nominal prior austenite grain sizes. This occurred because of the interdendritic segregation induced composition variations both enlarged and decreased by turns the grain sizes. The CET also reduced measured impact toughness values.
\end{abstract}

https://doi.org/10.1007/s11663-020-01997-4

(C) The Author(s) 2020

\section{INTRODUCTION}

Howe (1916) describes the basic principles of the formation of segregation in steel castings. Macroscopic variations in the composition of a casting by the gradual separation of the different chemical constituents during solidification are called macrosegregation and correspondingly the chemical heterogeneity at the scale of the microstructure is known as microsegregation. Both macro- and microsegregation originates from the partitioning of alloying elements between the solid and liquid phases coupled with the movement of the coexisting liquid and solid phases in the mushy zone ${ }^{[1]}$ Flemings ${ }^{[2]}$ summarized the state of knowledge about macrosegregation in the twentieth century in his review article. Generally, macrosegregation is the result of

S. KOSKENNISKA, A. KAIJALAINEN, D. PORTER, and J. KÖMI are with the Materials and Mechanical Engineering, Centre for Advanced Steel Research, University of Oulu, P.O. Box 8000, 90014, Oulu, Finland. Contact e-mail: sami.koskenniska@oulu.fi T. PIKKARAINEN and S. MEHTONEN are with the SSAB Europe Oy, Rautaruukintie 155, P.O. Box 93, 92101 Raahe, Finland.

Manuscript submitted December 13, 2019; accepted October 2, 2020.

Article published online October 28, 2020. interdendritic flow, driven by i.e., geometry, gravity, shrinkage, bulging, and solid deformation and in specific circumstances the settling of solid in the early steps of solidification. ${ }^{[2]}$ Ghosh $^{[3]}$ explained the fundamentals of microsegregation, which is confined to the micron-scale interdendritic spaces of the solidifying melt and can be alleviated by subsequent homogenization heat treatments unlike macrosegregation, which is therefore more harmful to the finished steel properties. Later refinements include treatment of dendrite tip undercooling and further research of microsegregation to more complex alloys. In the case of low-alloy steel solidification, accumulation of solute-enriched liquid leads to positive macrosegregation, for example on the centerline of the casting, and the settling of solute-lean solid regions leads to negative segregation. ${ }^{[3]} \mathrm{A}$ columnarto-equiaxed transition (CET) zone is formed once the equiaxed grains in the central part of the solidifying casting are present to prevent the columnar front movement. For example, Choudhary and Ghosh ${ }^{[4]}$ explained that the formation of an equiaxed zone demands the existence of solidification nuclei in the liquid and circumstances under which the nuclei growth and number density is sufficient to arrest the propagation of the columnar dendrites. ${ }^{[4]}$ High superheat 
increases the amount of columnar dendritic structure and when the superheat is high enough, the columnar dendrites can reach to the centerline of a continuously steel cast slab, while a low superheat can lead to a fully equiaxed dendritic structure as showed by Choudhary and Ganguly. ${ }^{[5]}$ With intermediary superheat in casting, the positive macrosegregation may appear at the CET boundary as Pikkarainen et al. proposed in their article. ${ }^{[6]}$ Zhang et al. have investigated the effect of filling velocity on positive macrosegregation and found that severity of macrosegregation was reduced when the filling rate was increased and secondary arm spacing became slightly smaller in the intermediate and final solidified zones. ${ }^{[7]}$ Dong, Gerin and Zhang ${ }^{[8-10]}$ have also modeled the macrosegregation phenomena in their recent articles. ${ }^{[8-10]}$

Ultrahigh-strength steels (UHSS) can be produced via thermomechanically controlled processing and direct quenching (TMCP-DQ), but typically reaustenitization followed by quenching and tempering is still used. In the TMCP-DQ process route, austenite conditioning is important as it affects both strength and toughness, as Tamura et al. ${ }^{[1]]}$ wrote in their comprehensive book about thermomechanical processing of high-strength low-alloy steels. Prior austenite grain (PAG) size is firstly refined by repetitive hot rolling reductions with recrystallization and then controllably deformed in the non-recrystallization temperature range to achieve the desired pancaked prior austenite microstructure. Austenite pancaking is seen as an efficient method to improve the mechanical properties without significantly compromising the uniform elongation as e.g., Kaijalainen et al. ${ }^{[12]}$ proposed.

This paper is concerned with the mechanical properties of a low-alloy TMCP-DQ martensitic ultrahigh-strength steel and how casting temperature and as-cast structure define the microstructure and mechanical properties after rolling and quenching. Particular emphasis was placed on isolating the effects of positive and negative macrosegregations on final hardness and on the formation and intensity of macrosegregation at the CET boundary. Studies concerning the quantification of macrosegregation morphologies and their effects on mechanical properties in industrial scale continuously cast steel flat products have been received relatively little attention. In particular, methodical research addressing these topics in continuously cast UHSS slabs is relatively limited. The present study has been undertaken with the aim of understanding how casting parameters can be optimized with respect to the mechanical properties of such steels.

\section{EXPERIMENTAL}

Experimental heats of a low-alloyed steel were continuously cast on a vertical — curved caster into $270 \mathrm{~mm}$ thick and $1975 \mathrm{~mm}$ wide slabs with two different superheats. The superheat for Cast 1 (Materials A, B, C) was $16{ }^{\circ} \mathrm{C}$ above the liquidus and for Cast 2
(Materials D, E) $34{ }^{\circ} \mathrm{C}$ above liquidus. The composition of the studied steel in wt pet was: $0.25 \mathrm{C}-1.1 \mathrm{Mn}-0.5 \mathrm{Si}-$ $0.4 \mathrm{Cr}-0.4 \mathrm{Ni}-0.2 \mathrm{Mo}-0.04 \mathrm{Al}-0.015 \mathrm{Ti}-0.0015 \mathrm{~B}$.

Three sets of samples intended for laboratory hot rolling and direct quenching were cut from Cast 1 as seen in Figure 1(a) and two sets of samples were cut from Cast 2 (Figure 1(b)). The hypothesis was that Cast 2 would have one Sample (D) without macrosegregation flaws and other (Sample E) with positive segregation at CET and centerline and negative segregation between them. Before hot rolling $10 \times 55 \times 80 \mathrm{~mm}^{3}$ slices were cut from the ends of the $180 \times 55 \times 80 \mathrm{~mm}^{3}$ minislabs and etched using Oberhoffer's reagent $\left(500 \mathrm{~mL} \mathrm{H}_{2} \mathrm{O}, 30\right.$ $\mathrm{g} \mathrm{FeCl}_{3}, 0.5 \mathrm{~g} \mathrm{SnCl}_{3}, 1 \mathrm{~g} \mathrm{CuCl}_{2}, 500 \mathrm{~mL}$ ethyl alcohol and $500 \mathrm{~mL} \mathrm{H}_{2} \mathrm{O}, 10$ to 20 seconds soaking time) to show the as-cast structure (Figure 3 ). The remaining 170 $\times 55 \times 80 \mathrm{~mm}^{3}$ minislabs were laboratory hot rolled (Carl Wezel Muhlacker) to the eventual plate thickness of $12 \mathrm{~mm}$ and direct-quenched in a water tank to room temperature at a cooling rate 40 to $60^{\circ} \mathrm{C} / \mathrm{s}$. Care was taken to mark the upper surfaces of the slabs and plates to allow corresponding positions to be identified. The hot rolling pass schedule was varied in order to separate the effects of hot rolling from those of as-cast structure and segregation patterns on the impact toughness. The rolling schedules had the finishing rolling temperatures (FRT) of $975{ }^{\circ} \mathrm{C}$ and $830{ }^{\circ} \mathrm{C}$ where the latter was achieved with waiting period after pass 4 between $1075^{\circ} \mathrm{C}$ and $920^{\circ} \mathrm{C}$ (Table I).

For analysis of the as-cast structure of the whole slab thickness, slabs were cut from the center of the transverse direction of the slabs to sample sizes of 20 $\mathrm{mm}$ (casting direction = CD), $270 \mathrm{~mm}$ (rolled plate normal direction $=$ ND) and $100 \mathrm{~mm}$ (transverse

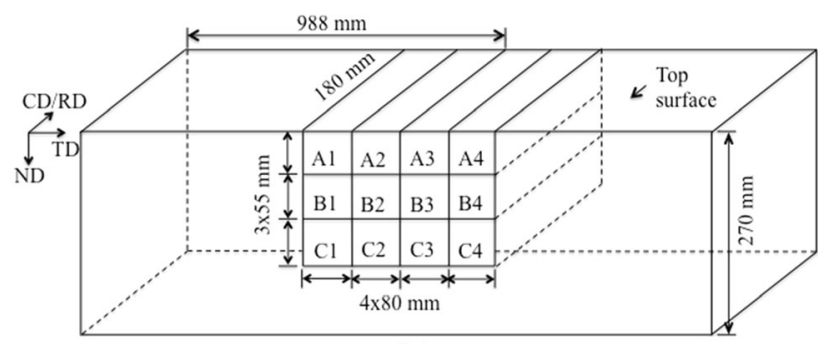

(a)

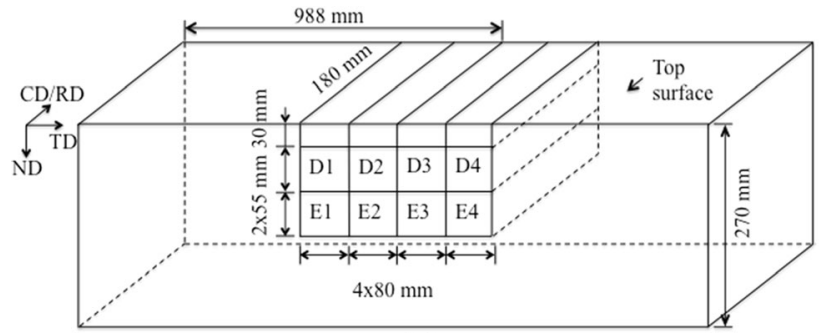

(b)

Fig. 1-Representation of the cutting of the slabs. $C D$, casting direction; $R D$, rolling direction; $N D$, rolled plate normal direction (same as slab thickness direction), $T D$, transverse direction. (a) Upper diagram for Cast $1\left(16^{\circ} \mathrm{C}\right.$ superheat) which was cut to 3 sets of samples A, B and C and (b) lower diagram for Cast $2\left(34{ }^{\circ} \mathrm{C}\right.$ superheat) which was cut to 2 sets of samples D and E. 
Table I. Hot Rolling Schedules

\begin{tabular}{|c|c|c|c|c|c|}
\hline \multicolumn{3}{|c|}{ Hot Rolling Schedule for FRT $975^{\circ} \mathrm{C}$} & \multicolumn{3}{|c|}{ Hot Rolling Schedule for FRT $830^{\circ} \mathrm{C}$} \\
\hline Pass & Thickness (mm) & Temperature $\left({ }^{\circ} \mathrm{C}\right)$ & Pass & Thickness (mm) & Temperature $\left({ }^{\circ} \mathrm{C}\right)$ \\
\hline & 55.0 & 1200 & & 55.0 & 1200 \\
\hline 1 & 46.5 & 1175 & 1 & 49.0 & 1175 \\
\hline 2 & 37.0 & 1140 & 2 & 40.5 & 1140 \\
\hline 3 & 29.5 & 1105 & 3 & 33.0 & 1105 \\
\hline 4 & 23.5 & 1075 & 4 & 27.0 & 1075 \\
\hline 5 & 19.0 & 1045 & pau & emperature drops & \\
\hline 6 & 15.1 & 1015 & 5 & 22.0 & 920 \\
\hline \multirow[t]{3}{*}{7} & 12.0 & 975 & 6 & 18.0 & 890 \\
\hline & & & 7 & 14.7 & 860 \\
\hline & & & 8 & 12.0 & 830 \\
\hline
\end{tabular}

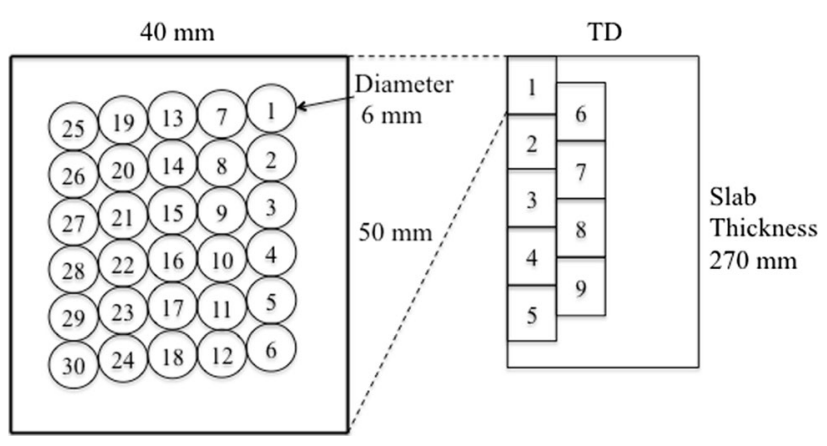

Fig. 2-Schematic presentation of OES-measurements.

direction $=$ TD) $($ Figure 2$)$. From these pieces, nine samples of $50 \times 40 \times 20 \mathrm{~mm}^{3}$ were cut for macrosegregation analyses as presented in Figure 2.

The slab samples were etched with $\mathrm{HCl}$ to show the macro-etched as-cast structure of the slabs (Figure 4). Etchant was 1:1 mixture of water and $100 \mathrm{pct} \mathrm{HCl}$ and soaking time was several minutes. An analysis matrix of 30 analysis places was applied as presented in Figure 2 using an optical emission spectrometer (OES, OBLF QSG 750, OBLF, Witten, Germany). Each analyzed point was $6 \mathrm{~mm}$ in diameter and by staggering the points as shown in Figure 2 it was possible to obtain mean values for the composition every $1 \mathrm{~mm}$ through the slab thickness.

The strength and ductility properties of the rolled samples were defined at room temperature using tensile testing (Zwick/Z100) at the uniform strain rate of 0.008 $\mathrm{s}^{-1}$ in accordance with the European standard EN 10002 using specimens with $6 \mathrm{~mm}$ diameter with their axis both in RD and TD. The strain was determined using an extensometer. Charpy-V notch impact testing was performed at $20^{\circ} \mathrm{C}$ intervals with three samples per temperature from $-60{ }^{\circ} \mathrm{C}$ to $0{ }^{\circ} \mathrm{C}$ and two samples per temperature from $+20^{\circ} \mathrm{C}$ to $40{ }^{\circ} \mathrm{C}$ using samples of 10 $\times 10 \times 55 \mathrm{~mm}^{3}$ taken both longitudinal $(\mathrm{T}-\mathrm{L})$ and transverse $(\mathrm{L}-\mathrm{T})$ relative to the rolling direction. Hardness was measured through the thickness of the hot-rolled and quenched plates with $0.5 \mathrm{~mm}$ intervals utilizing a Duramin-A300 (Struers) under a $50 \mathrm{~kg} / \mathrm{mm}^{2}$ load (HV5).
Microstructural inspections were executed utilizing optical microscopy (Nikon Eclipse MA100), laser scanning confocal microscope (LSCM) (VK-X200, Keyence Ltd) and field emission scanning electron microscope (FESEM, Zeiss Zigma). The PAG structure was quantified at the quarter-thickness of the laboratory rolled plates by the mean linear intercept method (MLI) with LSCM after picric acid etching (mixture of 4 pet picric acid and ethanol) with 10 to 30 seconds soaking time. Based on these measurements, the mean PAG size, aspect ratio, total reduction below the recrystallization temperature $\left(R_{\text {tot }}\right)$ and relative standard error were determined as described in Higginson and Sellars. ${ }^{[13]}$ Additionally, electron backscatter diffraction (EBSD) measurements were taken at sample centerlines with an accelerating voltage of $15 \mathrm{kV}$, working distance of 13 $\mathrm{mm}$ and step size $0.2 \mu \mathrm{m}$ from an area of $21500 \mu \mathrm{m}^{2}$ using (EDAX, TSL OIM Data Analysis software). The EBSD data enabled the determination of the mean effective grain size (d) and the effective grain size at 90 pct in the cumulative size distribution (d90 pct). EBSD grain sizes were expressed as equivalent circle diameters (ECD) and grain boundaries with a misorientation angle greater than $15 \mathrm{deg}$ were used to determine the effective grain size.

\section{RESULTS}

\section{A. As-cast structures}

The macrostructures of each sample are shown in Figure 3. Samples A, B and C were from Cast 1 with the lower superheat $\left(16^{\circ} \mathrm{C}\right)$ and samples $\mathrm{D}$ and $\mathrm{E}$ were from Cast 2 with the higher superheat $\left(34{ }^{\circ} \mathrm{C}\right)$, as seen in Table II. Two types of macrostructure could be identified: columnar dendritic and equiaxed dendritic. Samples A and D had fully columnar dendritic as-cast structure and $\mathrm{C}$ had a fully equiaxed dendritic structure. Sample B contained mostly a columnar dendritic structure with 20 pct equiaxed dendritic and a columnar-to-equiaxed transition (CET) zone between them. Sample E contained 30 pct columnar dendritic structure, an intense CET and 70 pct equiaxed dendritic structure. The columnar dendritic structure in the slab 


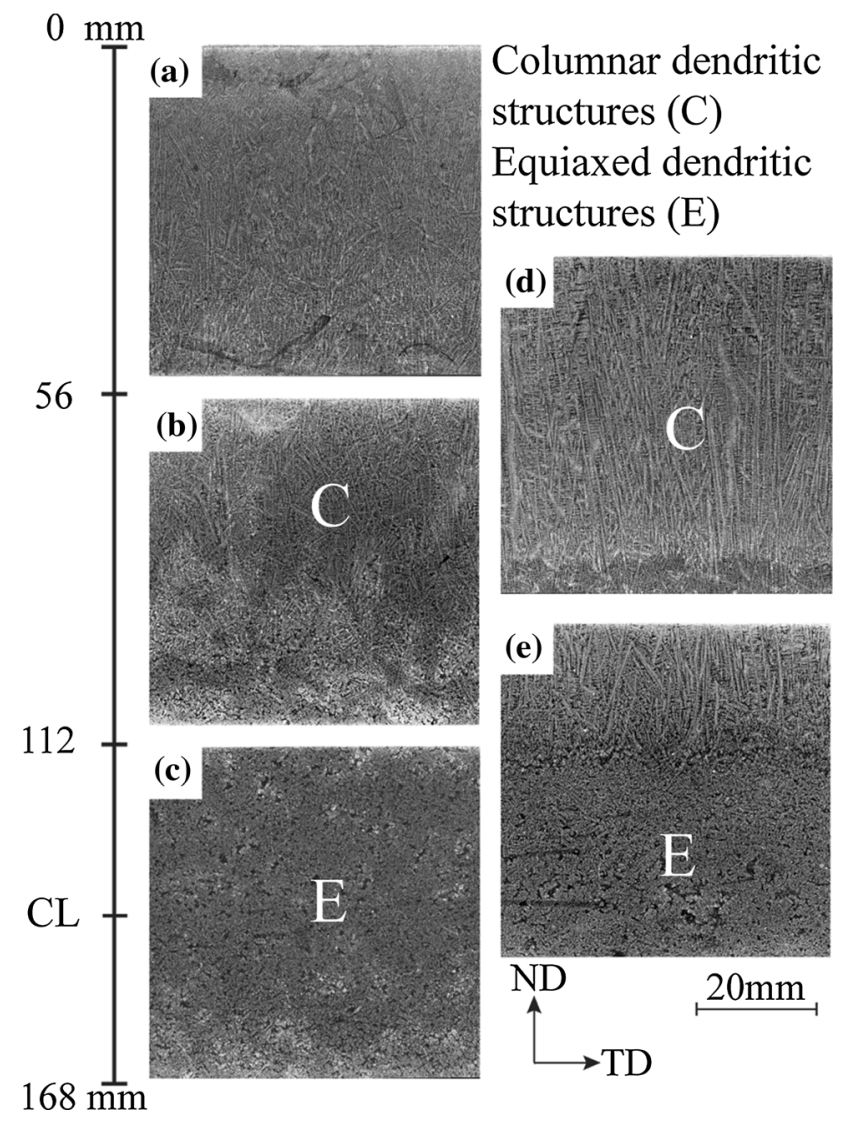

Fig. 3-The macrostructures of the investigated minislabs before laboratory rolling as seen on the TD/ND plane. Images $(a)$ to $(c)$ are samples A - C from Cast 1 and $(d)$ to $(e)$ are samples D and E from Cast 2 etched with Oberhoffer's reagent. Numbers on the left show distances from the upper surface of the $270 \mathrm{~mm}$ thick slab.

Table II. Approximate Macrostructure Percentages of Investigated Slabs

\begin{tabular}{lcrc}
\hline Sample & Superheat & Columnar (pct) & Equiaxed (pct) \\
\hline A & 16 & 100 & 0 \\
B & 16 & 80 & 20 \\
C & 16 & 0 & 100 \\
D & 34 & 100 & 0 \\
E & 34 & 30 & 70 \\
\hline
\end{tabular}

with higher superheat was also more well defined and perpendicular to the slab surface than in the slab with lower superheat because of the larger temperature gradient.

\section{B. Segregation in as-cast structures}

The bulk carbon content in Slab 1 (in Figure 4(a)) was 0.27 wt pct. This value is seen near the surfaces of the slab, but $50 \mathrm{~mm}$ from the upper surface, the $\mathrm{C}$ content started to gradually increase and fluctuate reaching a peak value of $0.30 \mathrm{wt}$ pct at the location of the upper CET zone, i.e., $110 \mathrm{~mm}$ from the upper surface. The carbon content started declining after 110 $\mathrm{mm}$ and reached a local minimum of $0.23 \mathrm{wt}$ pct at 120 $\mathrm{mm}$, which was midway between the upper CET and the centerline of the slab. From $120 \mathrm{~mm}$ to centerline at 135 $\mathrm{mm}$ the carbon content increased to 0.29 wt pct. Between the centerline and the lower CET at $165 \mathrm{~mm}$ there is another negatively segregated zone in which the minimum carbon content was $0.22 \mathrm{wt}$ pct at $150 \mathrm{~mm}$. The carbon content at the lower CET was close to nominal value and it stayed relatively constant all the way to the bottom of slab at $270 \mathrm{~mm}$. Overall, therefore the carbon content in Cast 1 with $16{ }^{\circ} \mathrm{C}$ superheat ranged from $0.22 \mathrm{wt}$ pet at $145 \mathrm{~mm}$ to $0.30 \mathrm{wt}$ pet at 104 $\mathrm{mm}$ from the upper surface.

The bulk carbon content in Slab 2 (in Figure 4(b)) with $34{ }^{\circ} \mathrm{C}$ superheat was 0.26 wt pct. The carbon content at the surface was 0.24 wt pct and it stayed relatively constant at this level down to a depth of 80 $\mathrm{mm}$ from the surface and then quite drastically grew from 0.24 to $0.32 \mathrm{wt}$ pct between 80 and $110 \mathrm{~mm}$. It is evident from Figure 4 that the positive segregation of $\mathrm{C}$ at the depth of $110 \mathrm{~mm}$ and the line showing the upper CET in the macro-etched image correspond to each other. From 110 to $125 \mathrm{~mm}$ the carbon content decreases rapidly from 0.32 to $0.22 \mathrm{wt}$ pct and increased from $125 \mathrm{~mm}$ to centerline at $140 \mathrm{~mm}$. Between the centerline and the lower CET at $165 \mathrm{~mm}$ there was negative segregation with a local minimum in the $\mathrm{C}$ concentration of $0.23 \mathrm{wt}$ pct at $150 \mathrm{~mm}$.

Table III shows the local chemical compositions at the negatively and positively segregated zones as percentages of the overall mean composition. All chemical components except aluminum behaved in the same way in Cast 1 . The most heavily segregated elements were $\mathrm{N}$, $\mathrm{Ti}$ and $\mathrm{C}$. The maximum carbon content at Cast 2 was $0.32 \mathrm{wt}$ pet at $109 \mathrm{~mm}$ and minimum $0.20 \mathrm{wt}$ pet at 140 $\mathrm{mm}$. The most negatively and positively segregated elements were carbon, nitrogen and titanium. The above observations are as expected from the partition coefficients of the elements between the liquid and solid phases (ferrite or austenite).

\section{Mechanical properties of rolled plates}

Tensile tests results are presented in Figure 5. When the finish rolling temperature (FRT) was $975^{\circ} \mathrm{C}$, tensile strengths varied between 1656 and $1790 \mathrm{MPa}$, and with FRT $830{ }^{\circ} \mathrm{C}$ between 1698 and $1871 \mathrm{MPa}$ (including both longitudinal and transverse test results). Thus, the average tensile strength with FRT $975^{\circ} \mathrm{C}$ was $65 \mathrm{MPa}$ lower than the average with FRT $830{ }^{\circ} \mathrm{C}$. Sample B (from Cast 1) had the highest tensile strengths with both finish rolling temperatures and testing directions while Sample D (from Cast 2) had the lowest values. The average tensile strength with Sample B was $1809 \mathrm{MPa}$ and with Sample D $1700 \mathrm{MPa}$, which can be at least partly explained by the 0.02 percentage point difference in the average amount of carbon in each sample.

Charpy V impact test results are given in Figure 6 and examples of the fracture surfaces of Charpy- $\mathrm{V}$ impact toughness specimens tested at $-40{ }^{\circ} \mathrm{C}$ are presented at Figure 7. Some of the specimens from Samples C and E have a split at the approximate location of the centerline 


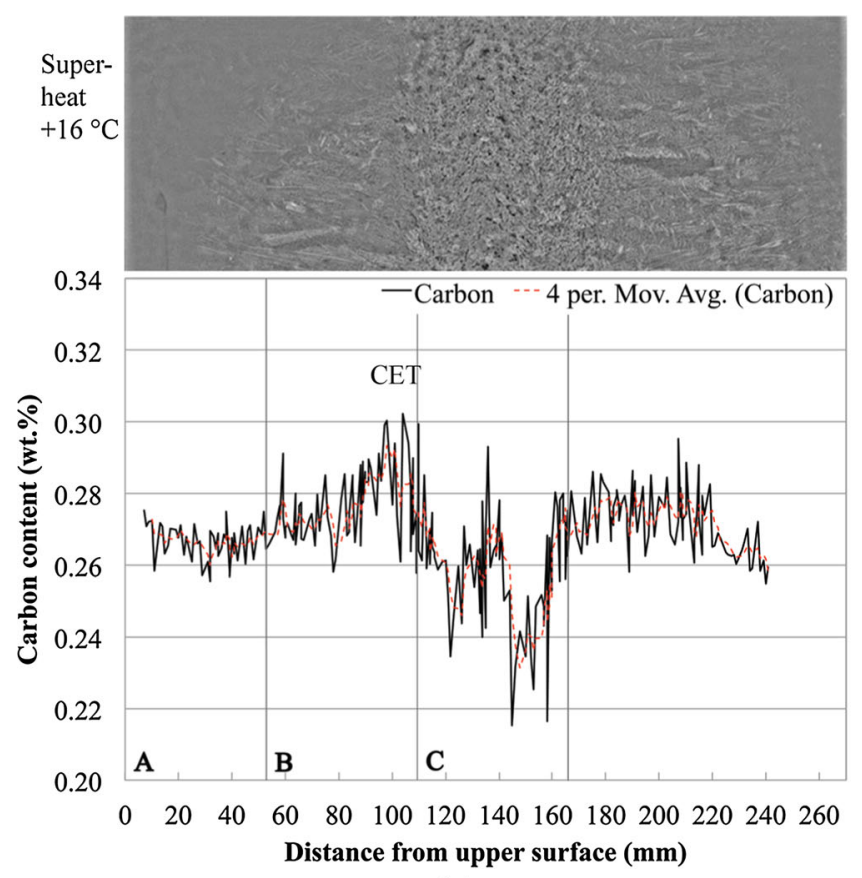

(a)

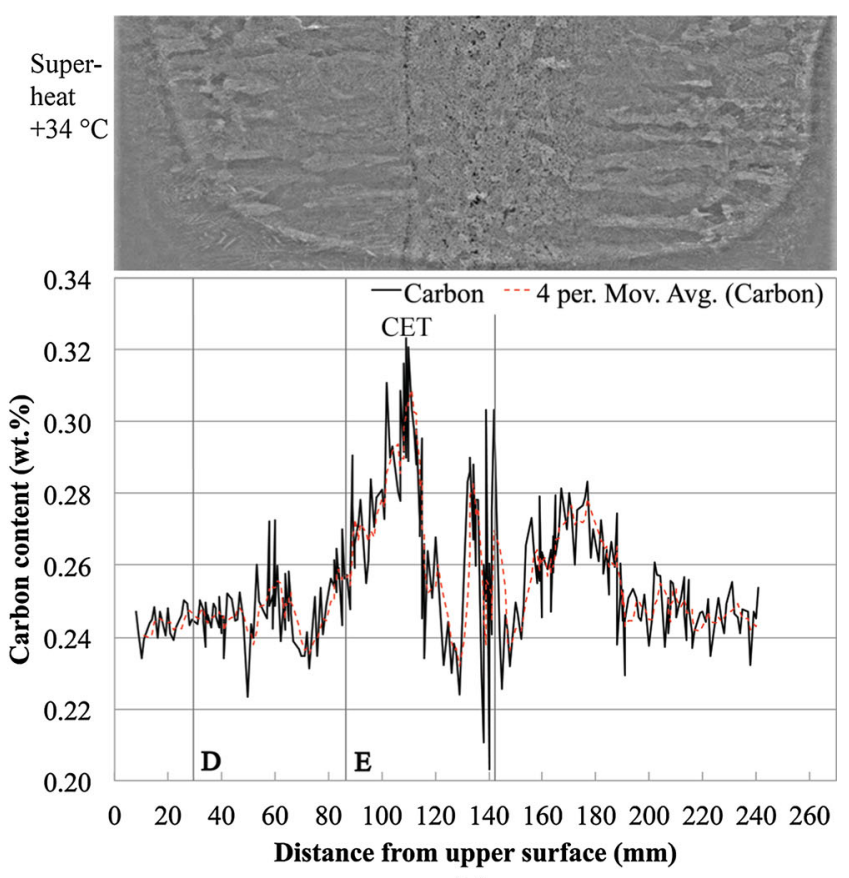

(b)

Fig. 4-Macrographs and OES carbon content profiles of slab $1(a)$ and $2(b)$. The locations of samples A-C from Cast 1 and samples D and E from Cast 2 are marked on the carbon concentration profiles. (The U-shaped contrast in the corners of the macrographs are caused by the slab plasma cutting).

and CET respectively. The maximum variation between Samples A-E in absorbed energy at $-60{ }^{\circ} \mathrm{C}$ was $10 \mathrm{~J}$ with an overall average of $22 \mathrm{~J}$, where samples with higher FRT of $975{ }^{\circ} \mathrm{C}$ had 1 to $8 \mathrm{~J}$ better impact toughness values than their lower FRT $830{ }^{\circ} \mathrm{C}$ counterparts. The maximum recorded differences in the mean absorbed energies between the different samples increases somewhat as the test temperature increases: it was $26 \mathrm{~J}$ at $0{ }^{\circ} \mathrm{C}$ and $34 \mathrm{~J}$ at $+40{ }^{\circ} \mathrm{C}$. At $+40{ }^{\circ} \mathrm{C}$ mean absorbed energies ranged from 36 to $70 \mathrm{~J}$. It can be seen from Figure 6, that Samples B and E which contained the CET in their as-cast structure showed the lowest the impact toughness values. The impact toughness difference between material samples with and without CET increases slightly with increasing test temperature. Neither FRT nor sample orientation with respect to the rolling direction affected the differences associated with the presence of the CET (Figure 8).

\section{Microstructures of Rolled Plates}

The prior austenite microstructures were determined from micrographs taken at the $1 / 4$ thickness of the hot rolled plates on both RD-ND and TD-ND sections. Examples of the PAG structures revealed by picric acid etching, are given in Figure 9 and examples of the microstructures revealed by Nital etching are given in Figure 10. It can be seen that the higher FRT of $975^{\circ} \mathrm{C}$ resulted in a more equiaxed austenite grain structure, while some pancaking, i.e., elongation of the grains in the rolling direction, had taken place when the FRT was $830{ }^{\circ} \mathrm{C}$. The grain sizes were measured using the mean linear intercept (MLI) method on RD-ND and TD-ND surfaces in order to distinguish the total reduction below the recrystallization temperatures $\left(R_{\text {tot }}\right)$ and mean prior austenite grain sizes (D). Mean prior austenite grain sizes varied from $15.4 \mu \mathrm{m}$ to $19.1 \mu \mathrm{m}$ with FRT of 830 ${ }^{\circ} \mathrm{C}$ and from $18.1 \mu \mathrm{m}$ to $20.5 \mu$ m with FRT of $975^{\circ} \mathrm{C}$ as seen in Table III.

As seen in Table IV, changing the FRT from $830{ }^{\circ} \mathrm{C}$ to $975{ }^{\circ} \mathrm{C}$ led to a slight increase in the PAG size. The effect was the smallest in Sample C, where difference was $0.4 \mu \mathrm{m}$ and the biggest in Sample D, where difference was $4.9 \mu \mathrm{m}$. The PAG size was slightly larger in the samples taken close to the surface of the slab than in the central parts. As expected, the prior austenite grains were more elongated with the lower FRT. The total reduction values below the recrystallization temperature for FRT $830{ }^{\circ} \mathrm{C}$ were 49.7 to 50.6 pct in Cast 1 and 43.7 to 45.4 pct in Cast 2. With FRT $975{ }^{\circ} \mathrm{C}$ the prior austenite grains were quite equiaxed with $R_{\text {tot }}$ values ranging from 11.2 to 22.4 pct, with the biggest values in each cast at the centerline.

Figure 11 contains EBSD images showing typical martensitic microstructures as already noticed in the laser scanning confocal microscope (LSCM) micrographs, the lower FRT $\left(830{ }^{\circ} \mathrm{C}\right)$ yielded a more pancaked austenite grain structure, while the higher FRT $\left(975{ }^{\circ} \mathrm{C}\right)$ resulted in equiaxed prior austenite grains.

The EBSD data was further used for calculating effective gain sizes, i.e., the ECD sizes of grains surrounded by boundaries with misorientation angles in the range 15 to $62.7 \mathrm{deg}$. The results are shown in Figure 11. The mean effective grain sizes were between 1.2 and $1.5 \mu \mathrm{m}$ for FRT $830^{\circ} \mathrm{C}$ and between 1.4 and 1.5 


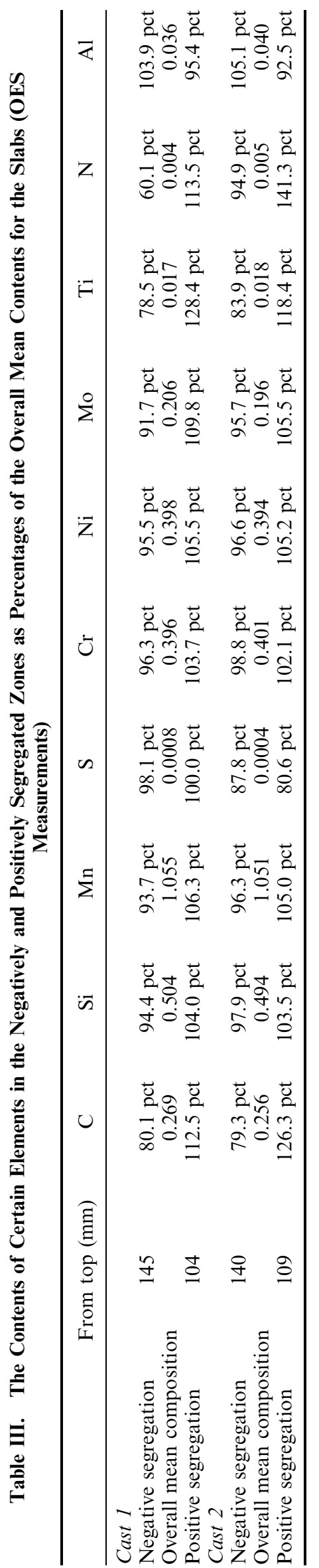

$\mu \mathrm{m}$ for FRT $975^{\circ} \mathrm{C}$. The 90 th percentile ECD effective grain sizes in the cumulative grain size distribution $\left(\mathrm{d}_{90 \mathrm{pct}}\right)$ were between 8.2 and $9.7 \mu \mathrm{m}$ for FRT $830{ }^{\circ} \mathrm{C}$ and between 8.0 and $11.3 \mu \mathrm{m}$ for FRT $975{ }^{\circ} \mathrm{C}$. The distribution of high-angle grain boundaries was quite homogenous in all the investigated specimens (Figure 12).

\section{DISCUSSION}

\section{A. Effect of the Process Parameters of Continuous Casting on the Formation of As-Cast Structure and Segregation Patterns}

The as-cast structures of the investigated samples consisted of fully columnar dendritic structure (Samples A and D), fully equiaxed dendritic structure (Sample C), 80 pct columnar and 20 pct equiaxed dendritic structure with macrosegregated CET (Sample B) and $30 \mathrm{pct}$ columnar and 70 pct equiaxed dendritic structure with intense macrosegregated CET (Sample E). The relative size of columnar and equiaxed dendritic zones in a continuously cast slab is affected by the superheat of the liquid steel. Higher superheat increases the size of the columnar zone since the nucleation of equiaxed dendrites is delayed as described by Krauss (2003). ${ }^{[14]}$

The slab samples cast with both high $\left(34^{\circ} \mathrm{C}\right)$ and low $\left(16{ }^{\circ} \mathrm{C}\right)$ superheat were seen to be depleted of carbon and other alloying elements in the areas between the CET and the centerline, while there were concentrations of the alloying elements at the CET boundary and at the centerline. This is a combined result of sedimentation of solute-poor equiaxed grains and interdendritic segregation in the mushy zone according to Flemings. ${ }^{[2]}$ Positive macrosegregation at the CET boundaries is a relatively unknown phenomenon in the literature but it has been shown to occur at intermediate superheats as Pikkarainen et al. showed in their research. ${ }^{[6]}$ The effect of interdendritic segregation can be seen as the carbon content increases gradually from the surface to the CET. Sedimentation of equiaxed grains and shrinkage induced by solidification of dendrites pushes the excess carbon and other solutes to the liquid interdendritic regions and towards the CET, where eventually a positive segregation form. Macrosegregation patterns were stronger when the superheat was $34^{\circ} \mathrm{C}$ compared with $16{ }^{\circ} \mathrm{C}$. In addition, the location of the CET was affected by the superheat: the $18^{\circ} \mathrm{C}$ higher superheat shifted the CET 5 $\mathrm{mm}$ towards the centerline. This phenomenon derives from the local cooling rate in continuous casting, which affects the primary and secondary arm spacing of the as-cast structure of the steel, which is consistent with the results of Kobayashi and Nagai. ${ }^{[15]}$ The amplitude of the composition fluctuations in the measured local carbon concentrations grows from 0.01 percentage units near the surface to 0.04 percent by weight at the CET. Simultaneously, the spatial separation between fluctuations grows in proportion with the growth of the secondary dendrite arm spacing as El-Bealy and Thomas disclosed in their article. ${ }^{[16]}$ 


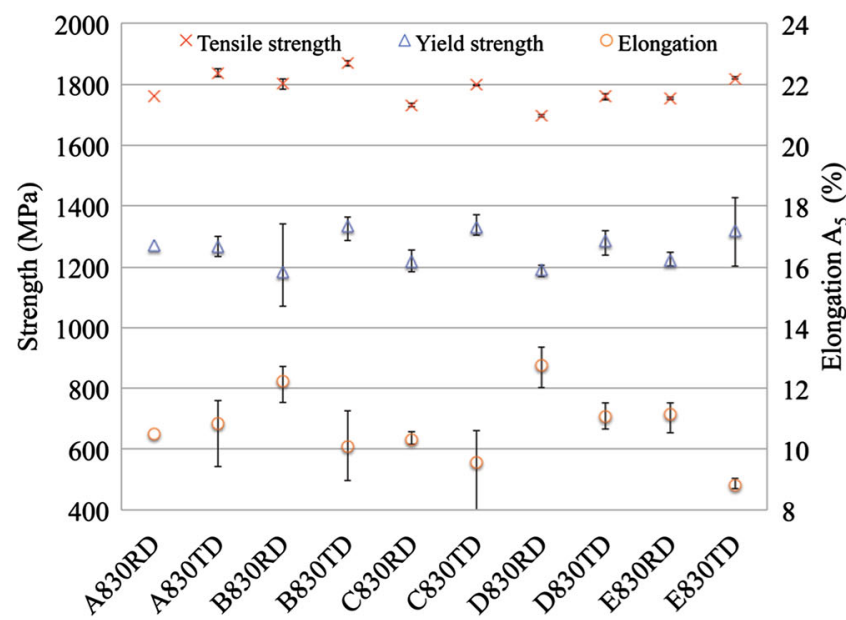

(a)

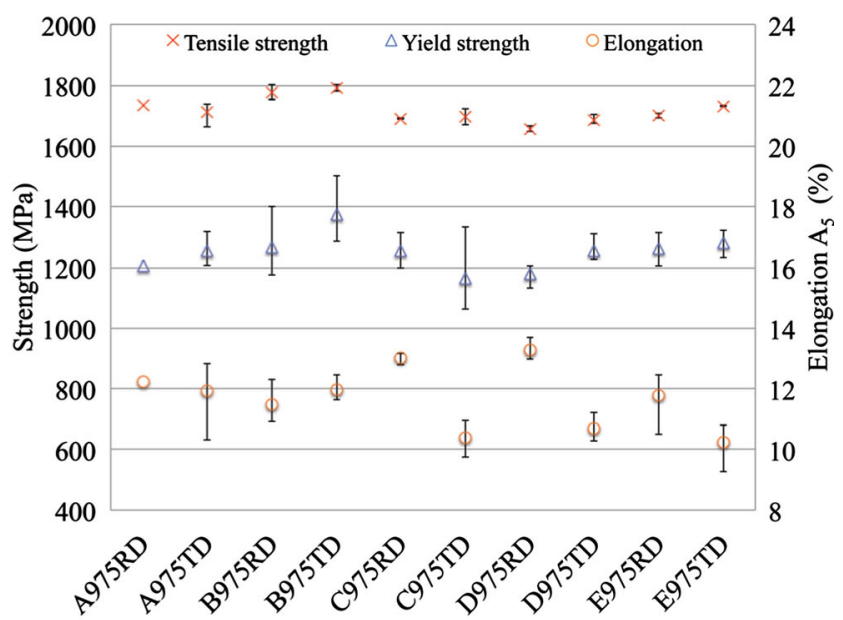

(b)

Fig. 5-Tensile and yield strength and elongation to fracture of Casts 1 and 2 with samples in the longitudinal (RD) and transverse directions (TD) with respect to the rolling direction. (a) FRT $830^{\circ} \mathrm{C},(b)$ FRT $975{ }^{\circ} \mathrm{C}$. Error bars show the minimum and maximum values.

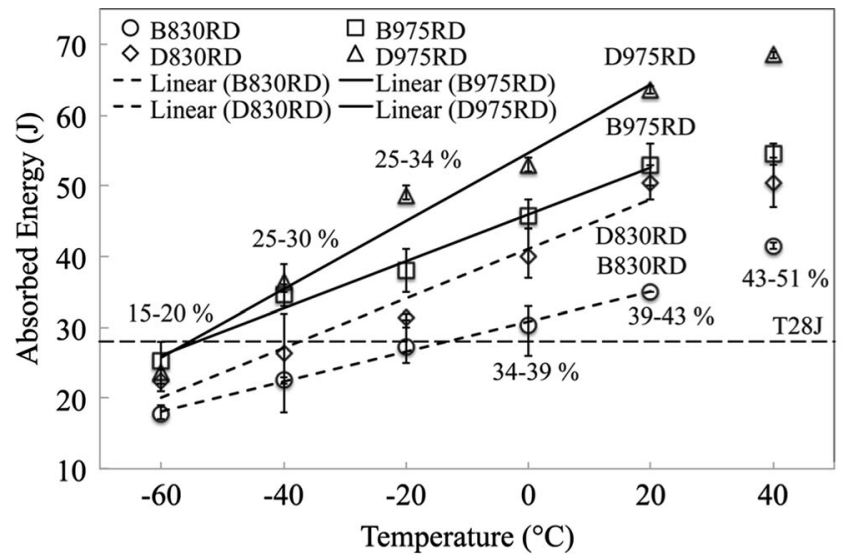

(a)

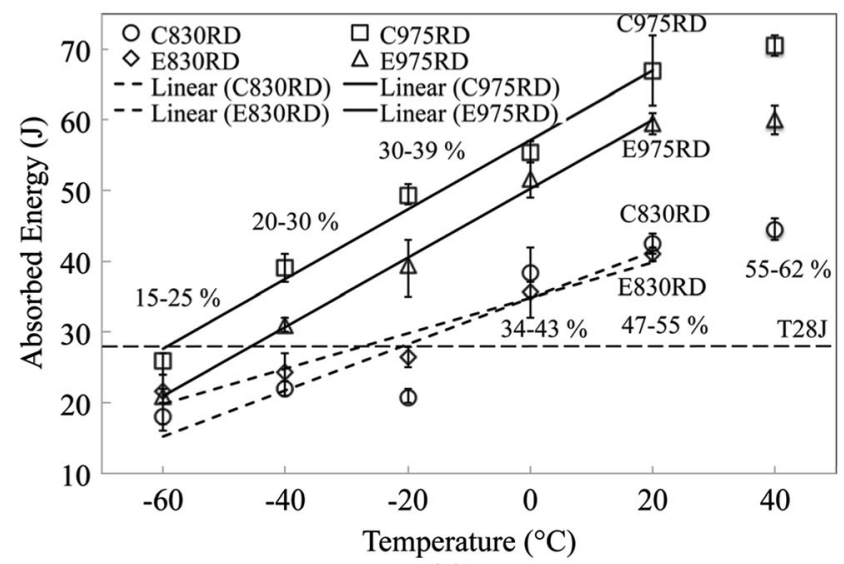

(c)

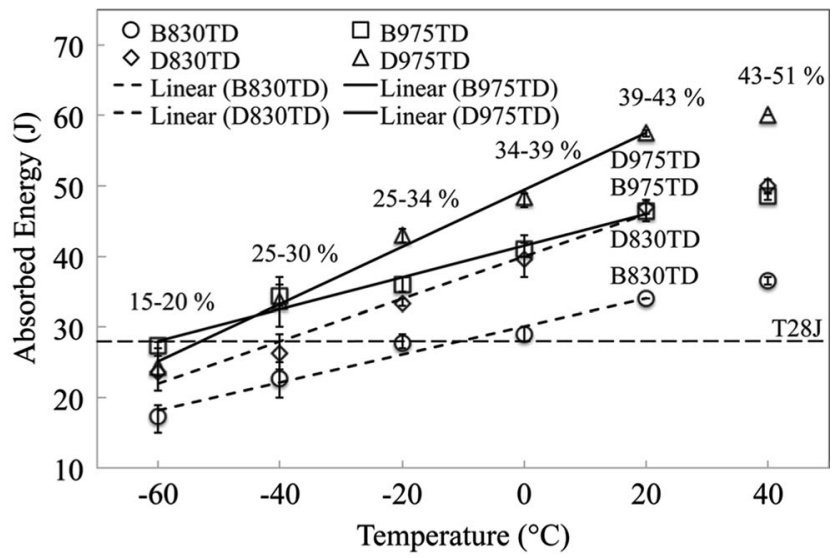

(b)

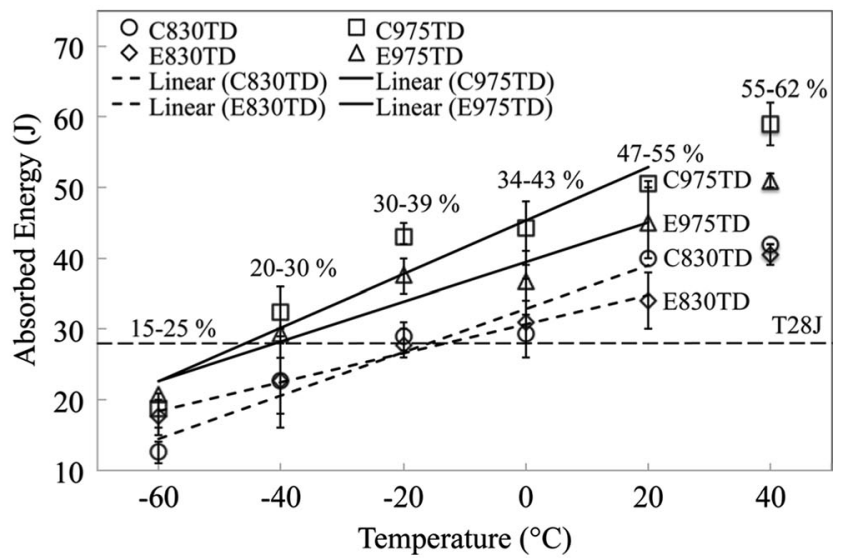

(d)

Fig. 6-Impact toughness transition curves. (a) and (b) Columnar dendritic structures with CET (B) and without CET (D) at RD and TD direction and $(c)$ and $(d)$ equiaxed dendritic structure without CET (C) and with CET (E) at RD and TD direction. Ductile fracture percentages are presented above or below each temperature. 


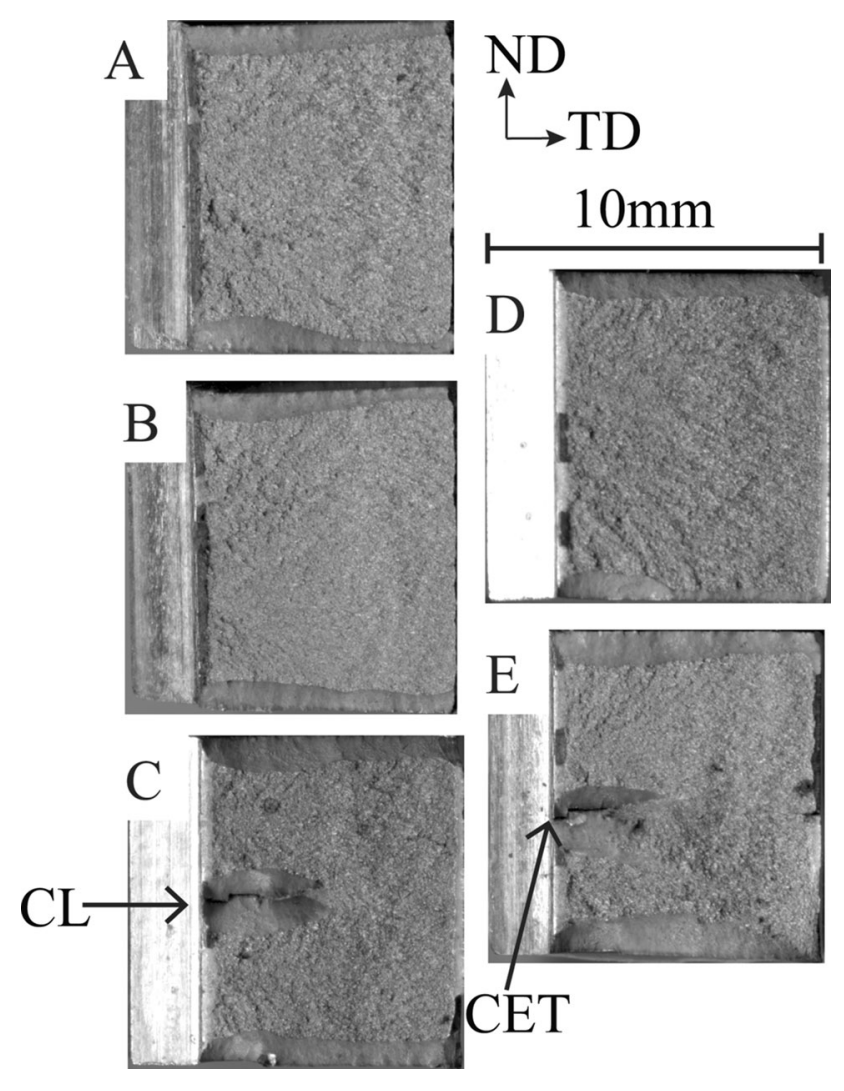

Fig. 7-ND-TD fracture surfaces of Charpy-V impact toughness specimens at $-40{ }^{\circ} \mathrm{C}$ from samples A-E with $830^{\circ} \mathrm{C}$ FRT.

\section{B. Impact of As-Cast Structures and Segregation on the Hot Rolled and Quenched Microstructures}

In the case of the studied laboratory rolled materials, the quenching time from the finish rolling temperature to room temperature was less than 20 seconds, which resulted in the formation of a fully martensitic structure. However, the cooling time on a production line could be 100 seconds and combined with fluctuations in the contents of the alloying elements might enable the emergence of ferritic and bainitic constituents in the negatively segregated zones, which would be detrimental to local hardness. The formation of non-martensitic constituents is more likely in the equiaxed cast structure near the centerline because of combined effects of negative macrosegregation and slower cooling rate.

From the macrographs in Figure 8 it is clear that the distance between the dark segregation bands and their intensity gradually increases with distance from the upper surface of the original slab through the rolled plates. This can also be seen from the carbon content profiles, which show increasing fluctuations as well as an increasing mean value with increasing depth. The carbon concentration fluctuations affected local hardness values, as can be clearly seen around the CET of Cast 2 for example, Figure 8(b). Finish rolling temperature did not have a significant effect on the hardness values. It is clear that the effects of segregation are inherited from the original casting through the heating and hot rolling. The effects are visible for example in hardness profiles, Charpy V separations, prior austenite images, macrographs and carbon concentration profiles.

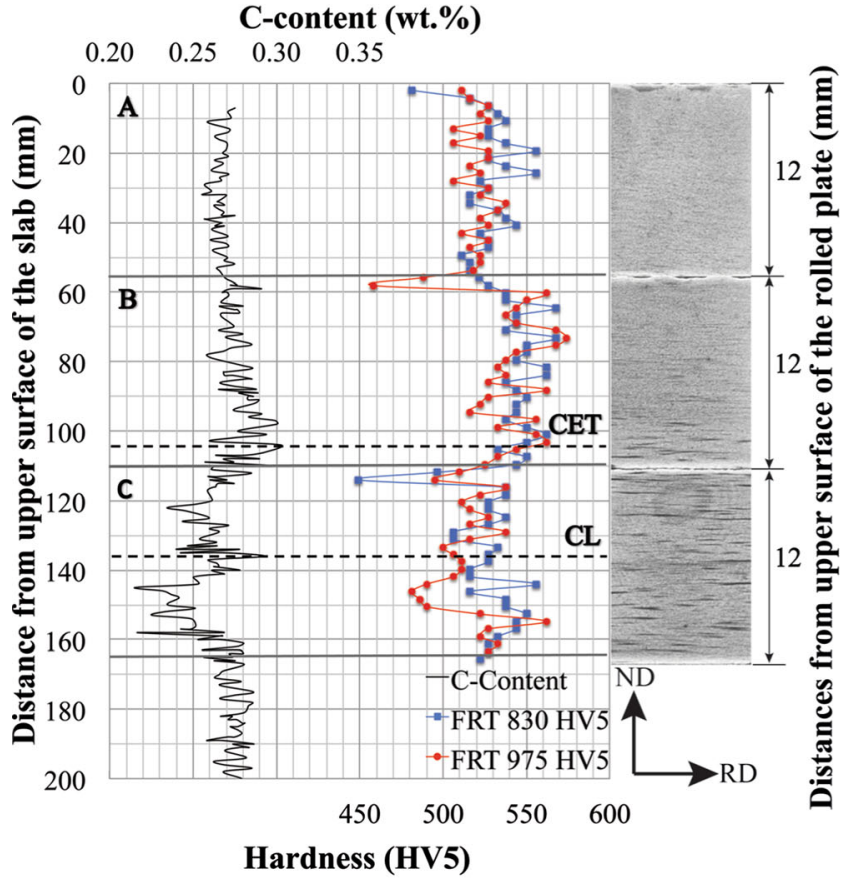

(a)

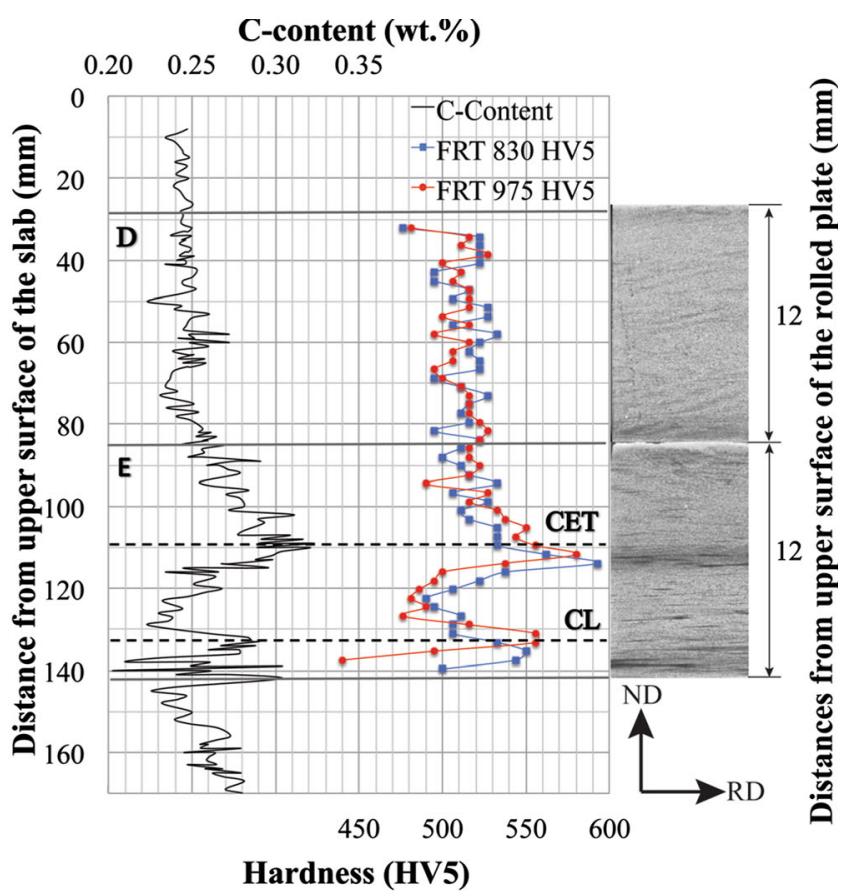

(b)

Fig. 8-Vickers hardness profiles (HV5) and LSCM macrographs from RD-ND sections of laboratory hot rolled and direct quenched samples together with OES carbon content profiles from the slabs. The macrographs are from FRT $975{ }^{\circ} \mathrm{C}$ samples using 2 pct Nital etching. Carbon concentration profiles, hardness profiles and the macrographs have been scaled to produce matching between the slabs and plates. (a) Cast 1 and (b) Cast 2. 

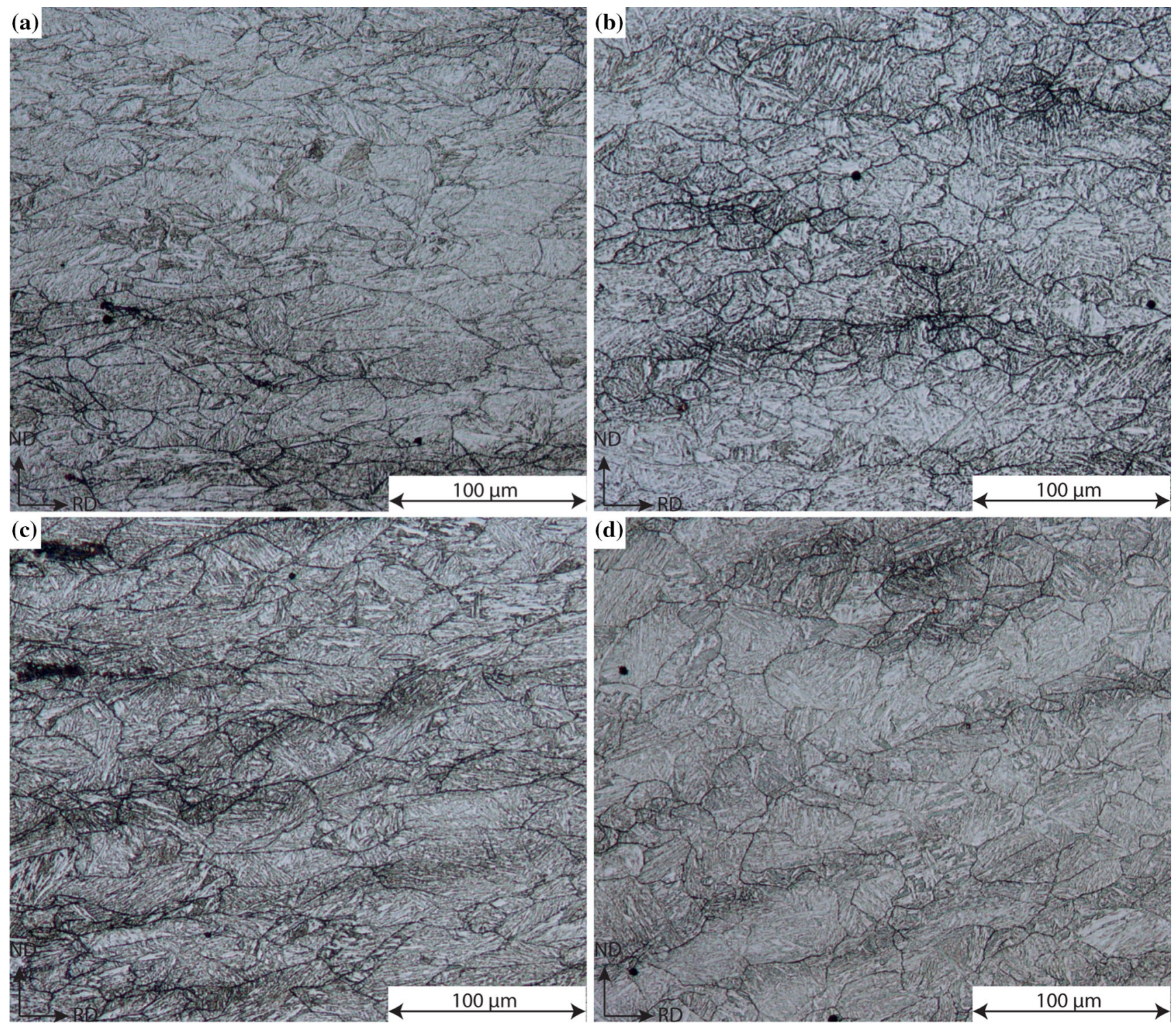

Fig. 9-Prior austenite grain structures taken at the quarter-thickness position after laboratory hot rolling. (a) Sample B FRT $830{ }^{\circ} \mathrm{C}$, (b) Sample B FRT $975^{\circ} \mathrm{C},\left(\right.$ c) Sample D FRT $830^{\circ} \mathrm{C}$ and $\left(\right.$ d) Sample D FRT $975^{\circ} \mathrm{C}$. LSCM, Picral etching.

The Charpy V fracture surfaces showed predominantly brittle features, i.e., intragranular cleavage cracks. The percentage brittle fracture only began to fall below 50 pct at room temperature and above. The observed absorbed energy values are therefore mainly controlled by the ease of cleavage crack nucleation and propagation, which are controlled by the strength of the steel, the effective grain size and the morphology and distribution of brittle inclusions affects according to Anderson. ${ }^{[17]}$ Impact tests showed that the samples that contained the CET zone, B and E, showed clearly lower absorbed energies in impact toughness testing than the CET-free samples, D and C, Figure 6.

Carbon induced separations at the center of the cleavage of the Charpy V samples (C and E), which is more detrimental at absorbed energy values than same structure at the start or end of the cleavage like in i.e., B (in Figure 7), because of the differences at the fracture growth forces and their direction, which is explained by Sencic and Leskov. ${ }^{[18]}$ Separations were more pronounced with the more pancaked $830{ }^{\circ} \mathrm{C}$ FRT and separation severity increased with decreasing test temperature until $-60{ }^{\circ} \mathrm{C}$, where the specimen fractured in a predominantly cleavage manner.

Prior austenite grain size affects the strength of martensitic microstructures by controlling the size of lath martensite blocks as per Krauss. ${ }^{[19]}$ Furthermore, refining the equiaxed austenite grain structures during rolling at recrystallization temperatures has been seen to somewhat improve the toughness properties according to Kaijalainen et al. ${ }^{[12]}$ Bracke et al. have noted that hot rolling in the non-recrystallization regime increased the strength and decreased the impact toughness of direct quenched martensite when $R_{\text {tot }}$ values were between 30 and 50 pct, but increased the impact toughness to the same level as the equiaxed grain structure when $R_{\text {tot }}$ was 

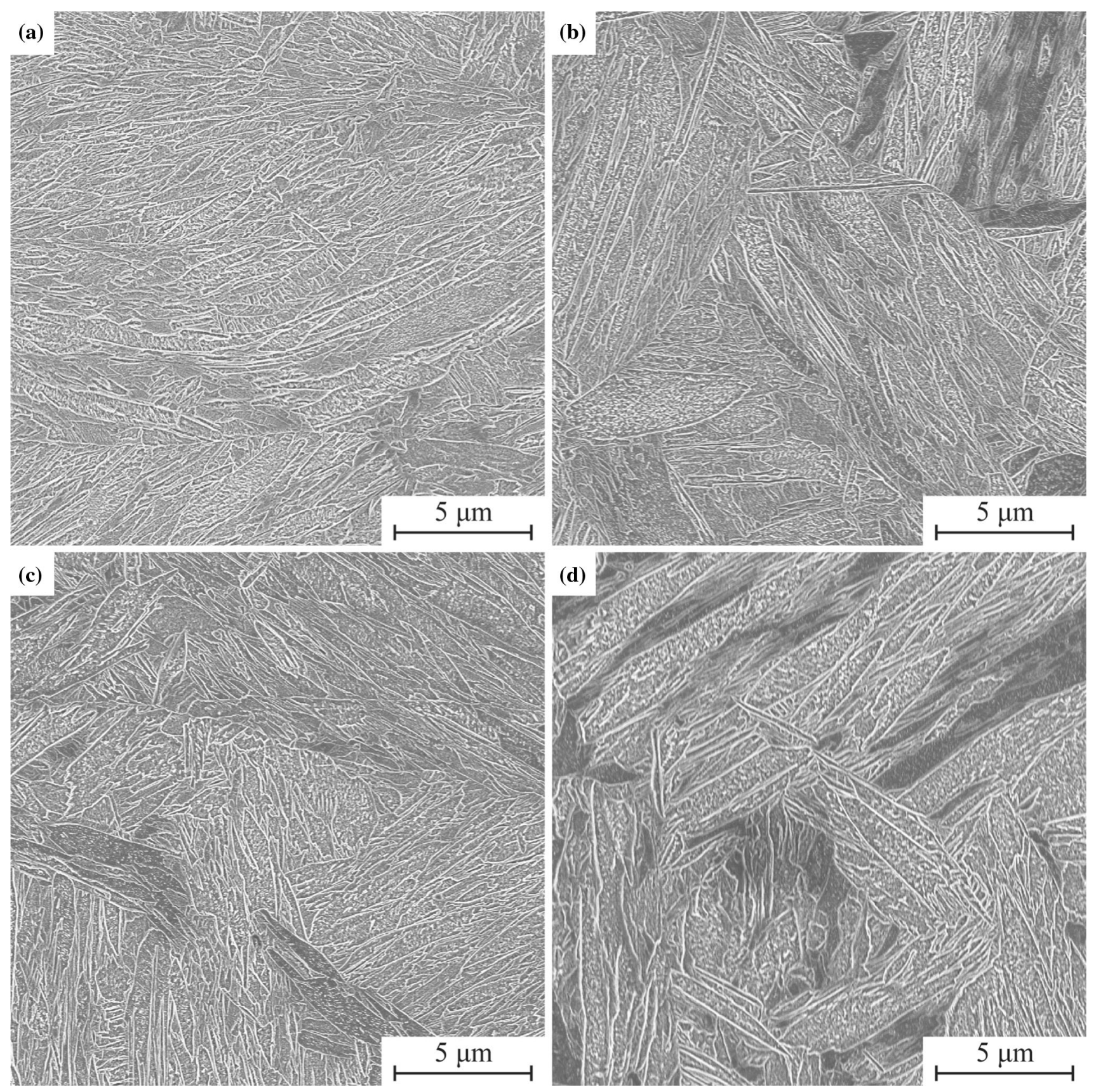

Fig. 10-Microstructures taken at the quarter-thickness of laboratory hot rolled $(a)$ B $830{ }^{\circ} \mathrm{C},(b)$ B $975{ }^{\circ} \mathrm{C},(c) \mathrm{D} 830{ }^{\circ} \mathrm{C}$ and $(d) \mathrm{D} 975{ }^{\circ} \mathrm{C}$ samples. Nital etching, FESEM SEI.

greater than 50 pct. $^{[20]}$ The two casting scenarios were hot rolled with $975^{\circ} \mathrm{C}$ and $830^{\circ} \mathrm{C}$ FRT's to distinguish the effect of grain size from effect of macrosegregation and as-cast structure and as a result the PAGS was more pancaked with the lower FRT $\left(R_{\text {tot }}=43.7\right.$ to $50.6 \mathrm{vs}$ 11.2 to $22.4 \mathrm{pct}$ ). The lower FRT also led to slightly smaller mean effective grain sizes. These differences at the prior austenite grain sizes and at the martensite lath sizes are so small that they could not explain differences at the mechanical properties.
Visual inspection of austenite grain size in the micrographs of the Picral etched specimens, i.e., Figure 9(b), suggests that positively segregated bands had significantly smaller austenite grain size than negatively segregated zones. This is to be expected since, for carbon contents higher than $0.17 \mathrm{wt}$ pct, it has been reported by Yasumoto et al. that higher carbon concentration decreases austenite grain growth in the cast state. ${ }^{[21]}$ Also, we have seen that the carbon-rich regions also contain high contents of all the alloying elements other 
Table IV. MLI Measurements of the PAG Along the Three Principal Directions Relative to the Rolling Direction at the 1/4 Thickness of the Plate Together with the Calculated Total Reduction Below the Recrystallization Temperature $\left(R_{\text {tot }}\right)$ and the Mean Prior Austenite Grain Size (D)

\begin{tabular}{|c|c|c|c|c|c|}
\hline Sample & $\mathrm{ND}(\mu \mathrm{m})$ & $\mathrm{RD}(\mu \mathrm{m})$ & $\mathrm{TD}(\mu \mathrm{m})$ & $R_{\mathrm{tot}}(\mathrm{pct})$ & $D(\mu \mathrm{m})$ \\
\hline A 830 & $10.1 \pm 0.4$ & $41.3 \pm 2.1$ & $16.9 \pm 0.8$ & $50.6 \pm 0.7$ & $19.1 \pm 0.5$ \\
\hline B830 & $8.5 \pm 0.3$ & $34.2 \pm 1.6$ & $16.9 \pm 0.8$ & $50.1 \pm 0.5$ & $17.0 \pm 0.4$ \\
\hline $\mathrm{C} 830$ & $8.7 \pm 0.3$ & $34.2 \pm 1.6$ & $18.8 \pm 0.9$ & $49.7 \pm 0.5$ & $17.7 \pm 0.5$ \\
\hline D830 & $8.2 \pm 0.3$ & $27.5 \pm 1.1$ & $16.2 \pm 0.8$ & $45.4 \pm 0.4$ & $15.4 \pm 0.4$ \\
\hline E830 & $8.0 \pm 0.3$ & $25.3 \pm 1.0$ & $18.3 \pm 0.9$ & $43.7 \pm 0.4$ & $15.5 \pm 0.4$ \\
\hline A975 & $20.4 \pm 1.0$ & $25.9 \pm 1.2$ & $16.3 \pm 0.8$ & $11.2 \pm 0.7$ & $20.5 \pm 0.5$ \\
\hline B975 & $19.2 \pm 0.9$ & $26.8 \pm 1.2$ & $15.4 \pm 0.7$ & $15.2 \pm 0.7$ & $19.9 \pm 0.5$ \\
\hline C975 & $16.1 \pm 0.7$ & $26.6 \pm 1.2$ & $13.9 \pm 0.6$ & $22.4 \pm 0.6$ & $18.1 \pm 0.5$ \\
\hline D975 & $18.4 \pm 0.8$ & $27.6 \pm 1.3$ & $16.4 \pm 0.8$ & $18.3 \pm 0.7$ & $20.3 \pm 0.5$ \\
\hline E975 & $16.4 \pm 0.7$ & $24.8 \pm 1.1$ & $15.3 \pm 0.7$ & $18.8 \pm 0.6$ & $18.4 \pm 0.5$ \\
\hline
\end{tabular}

95 pct confidence limits of the means are given.
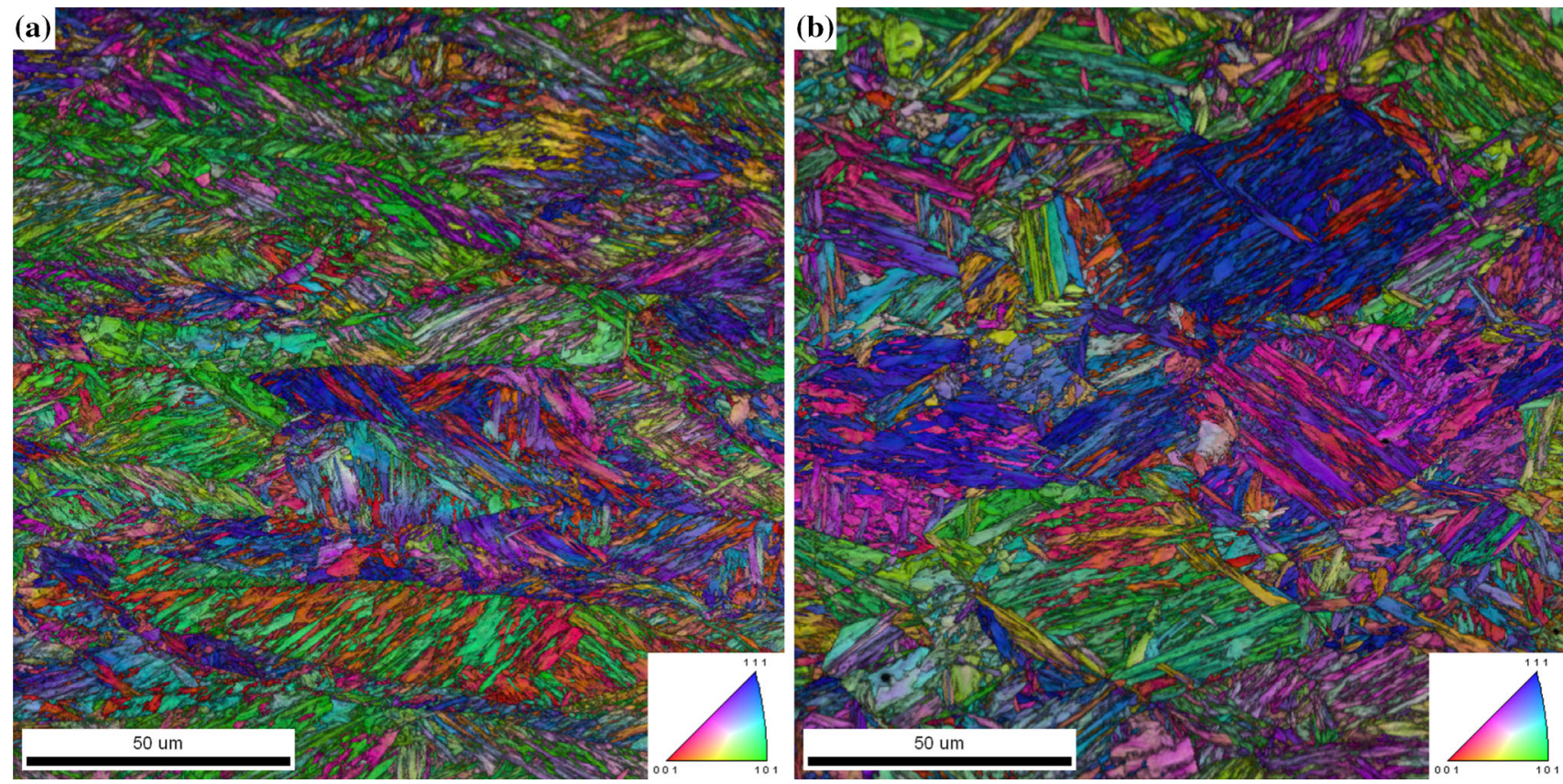

Fig. 11-EBSD maps with IPF coloring of typical microstructures in hot-rolled specimens $(a)$ D830 and (b) D975. RD-ND sections. Colors represent the orientation of the RD.

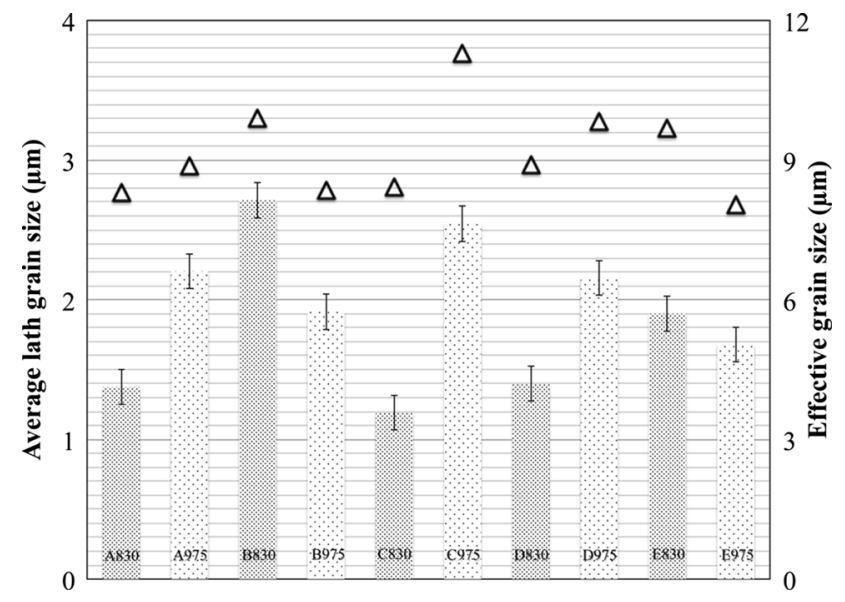

Fig. 12-Mean effective grain sizes and $\mathrm{d}_{90 \mathrm{pct}}$ grain sizes. Mean effective grain sizes as bars and $d_{90 p c t}$ grain sizes as hollow triangles. than aluminum. These, too, should hinder grain growth through solute drag effects. On top of these effects, Reiter et al. have reported that the mean as-cast austenite grain size varies across the slab thickness rising gradually with increasing distance from slab surface because of the decreasing temperature gradient, but it falling again near the centerline. ${ }^{[22]}$

\section{SUMMARY}

The effect of as-cast structure and macrosegregation on the toughness and tensile properties in directquenched martensitic steel has been investigated by using two different superheats and hot rolling finishing temperatures. The main results can be summarized as follows: 
1. Interdendritic segregation was more intense with higher $\left(+34{ }^{\circ} \mathrm{C}\right)$ superheat than lower $\left(+16^{\circ} \mathrm{C}\right)$ and led to more pronounced macrosegregation, as expected. This is because the increased slab temperature promotes the diffusion of segregated elements.

2. Segregation was positive at the CET and centerline and negative at the equiaxed dendritic structure between them, which is a combined result of sedimentation of solute-poor equiaxed grains and interdendritic segregation in the mushy zone.

3. Macrosegregation that occurs during solidification was inherited in the hot rolled samples and caused loss of hardness in the negatively segregated equiaxed zone.

4. Samples containing the columnar to equiaxed transition (CET) had a up to $10 \mathrm{~J}$ less impact toughness on average. Increased carbon content promoted predominantly brittle features, which controlled the cleavage crack nucleation and propagation.

5. Positively microsegregated bands had smaller prior austenite grain sizes than negatively segregated zones, because the segregation of austenite grain growth controlling elements.

6. The slab produced with lower superheat led to enhanced and more uniform mechanical properties and is therefore the more advisable option.

\section{ACKNOWLEDGMENTS}

This work has been within the SIMP program of the Digital, Internet, Materials \& Engineering Co-Creation DIMECC ltd. We gratefully acknowledge the financial support from the Finnish funding agency for innovation Tekes and the companies participating in the program.

\section{FUNDING}

Open access funding provided by University of Oulu including Oulu University Hospital.

\section{OPEN ACCESS}

This article is licensed under a Creative Commons Attribution 4.0 International License, which permits use, sharing, adaptation, distribution and reproduction in any medium or format, as long as you give appropriate credit to the original author(s) and the source, provide a link to the Creative Commons licence, and indicate if changes were made. The images or other third party material in this article are included in the article's Creative Commons licence, unless indicated otherwise in a credit line to the material. If material is not included in the article's Creative Commons licence and your intended use is not permitted by statutory regulation or exceeds the permitted use, you will need to obtain permission directly from the copyright holder. To view a copy of this licence, visit http://creativec ommons.org/licenses/by/4.0/.

\section{REFERENCES}

1. H.M. Howe: The Metallography of Steel and Cast Iron, First Edit, McGraw-Hill, New York, Ny, 1916.

2. M.C. Flemings: ISIJ Int., 2000, vol. 40, pp. 833-41

3. A. Ghosh: Sadhana, 2001, vol. 26, pp. 5-24.

4. S.K. Choudhary and A. Ghosh: ISIJ Int., 1994, vol. 34, pp. 33845.

5. S.K. Choudhary and S. Ganguly: ISIJ Int., 2007, vol. 47, pp. 1759-66.

6. T. Pikkarainen, V. Vuorenmaa, I. Rentola, M. Leinonen, and D. Porter: in 4th International Conference on Advances in Solidification Processes (ICASP-4), at Windsor, UK, 2014.

7. C. Zhang, A. Loucif, M. Jahazi, R. Tremblay, and L.P. Lapierre: Appl. Sci., 2018, https://doi.org/10.3390/app8101878.

8. Q. Dong, J. Zhang, Y. Yin, and B. Wang: Metals, 2017, https:// doi.org/10.3390/met7060209.

9. B. Gerin, H. Combeau, M. Založnik, I. Poitrault, and M. Cherif: IOP Conf. Ser. Mater. Sci. Eng., 2020, https://doi.org/10.1088/ $1757-899 x / 861 / 1 / 012032$.

10. C. Zhang, D. Shahriari, A. Loucif, H. Melkonyan, and M. Jahazi: Int. J. Adv. Manuf. Technol., 2018, vol. 99, pp. 3035-48.

11. I. Tamura, H. Sekine, and T. Tanaka: Thermomechanical Processing of High-Strength Low-Alloy Steels, Butterworth \& Co, UK, 1988.

12. A.J. Kaijalainen, P.P. Suikkanen, T.J. Limnell, L.P. Karjalainen, J.I. Kömi, and D.A. Porter: J. Alloys Compd., 2013, vol. 577, pp. $642-8$.

13. R.L. Higginson and C.M. Sellars: 2003.

14. G. Krauss: Metall. Mater. Trans. B, 2003, vol. 34B, pp. 781-92.

15. Y. Kobayashi and K. Nagai: J. JSEM, 2014, vol. 14, pp. 216-20.

16. M. El-Bealy and B.G. Thomas: Metall. Mater. Trans. B, 1996, vol. 27B, pp. 689-93.

17. T.L. Anderson: Fracture Mechanics: Fundamentals and Applications, 2nd ed., CRC, New York, 1994.

18. B. Sencic and V. Leskov: 2012, vol. 46, pp. 489-96.

19. G. Krauss: Mater. Sci. Eng. A, 1999, vols. 273-275, pp. 40-57.

20. L. Bracke, W. Xu, and T. Waterschoot: Mater. Today Proc., 2015, vol. 2, pp. S659-62.

21. K. Yasumoto, T. Nagamichi, Y. Maehara, and K. Gunji: Tetsu-to-Hagané, 1987, vol. 73, pp. 1738-45.

22. J. Reiter, C. Bernhard, and H. Presslinger: Mater. Charact., 2008, vol. 59 , pp. 737-46.

Publisher's Note Springer Nature remains neutral with regard to jurisdictional claims in published maps and institutional affiliations. 